\title{
PRESENCE OF THE GENUS GIRIDIA, SPHENOPHYTE, IN THE PARANÁ BASIN (LOWER PERMIAN, RIO BONITO FORMATION)
}

\author{
DAIANA ROCKENBACH BOARDMAN \& ROBERTO IANNUZZI \\ Depto. de Paleontologia e Estratigrafia, UFRGS, Av. Bento Gonçalves, 9500, 91509-900, Porto Alegre, RS, Brasil. \\ daiana.boardman@gmail.com, roberto.iannuzzi@ufrgs.br
}

\begin{abstract}
The Bainha Outcrop, located in the Municipality of Criciúma, Santa Catarina State, corresponds to deposits of the "Irapuá Bed," Rio Bonito Formation, and it is considered one of the richest phytofossiliferous sites of the Paraná Basin, representative of the "Glossopteris Flora." However, the Sphenophytes are poorly represented in this taphoflora. In this contribution, some so far unpublished samples are analyzed, which allowed us to confirm, for the first time, the occurrence of the Indian morphogenus Giridia in the Lower Permian of the Basin. Two distinct morphotypes are considered. One is related to the type-species of the genus, referred to herein as Giridia indica and found only at the Bainha Outcrop. The other is described as a new species, Giridia quiteriensis sp. nov., recorded at both Bainha and Quitéria outcrops, the latter located in the municipality of Encruzilhada do Sul, Rio Grande do Sul State. The second morphotype corresponds to the material classified previously as Gondwanostachys australis, which was revised herein. Therefore, this is the first record of the genus Giridia outside India, which reinforces the relative floristic similarities between Indian and South American regions of Gondwana during the Early Permian.
\end{abstract}

Key words: Sphenophyte, Giridia, Lower Permian, Rio Bonito Formation, Paraná Basin, Southern Brazil.

\begin{abstract}
RESUMO - O afloramento Bainha, situado no município de Criciúma, SC, corresponde a depósitos da "Camada Irapuá", Formação Rio Bonito, é considerado um dos mais ricos sítios fitofossílíferos da bacia do Paraná, representativo da "Flora Glossopteris". Apesar disso, as esfenófitas são pouco representativas nesta tafoflora. Neste trabalho são analisados alguns exemplares até o momento inéditos que possibilitaram confirmar, pela primeira vez, a ocorrência do morfogênero indiano Giridia para os depósitos do Permiano Inferior da bacia. Trata-se de dois morfotipos distintos, um considerado afim à espécie tipo do gênero, classificado aqui como Giridia indica e presente apenas no afloramento Bainha, o outro descrito como uma nova espécie, Giridia quiteriensis sp. nov., registrado nos afloramentos Bainha e Quitéria, em Encruzilhada do Sul, RS. Este último corresponde ao material anteriormente classificado como Gondwanostachys australis que foi aqui reavaliado. Deste modo, este é o primeiro registro do gênero Giridia fora do território indiano, estreitando ainda mais a afinidade entre as floras gonduânicas da Península Índica e do continente sul-americano.
\end{abstract}

Palavras-chave: Sphenophyte, Giridia, Permiano Inferior, Formação Rio Bonito, bacia do Paraná, Sul do Brasil.

\section{INTRODUCTION}

The Bainha Outcrop, located in the municipality of Criciúma, Santa Catarina State (Figure 1), corresponds to deposits of the "Irapuá Bed", third coal bed of the Siderópolis Member, upper portion of the Rio Bonito Formation, middleupper portion of the Tubarão Group (Figure 2), and it is considered one of the richest fossil plant sites in the Paraná Basin. This outcrop, and some nearby localities (Bairro 20, Hospital and São Marcos outcrops), have been studied since the mid-1940s, showing a diversified megaflora composed of axis fragments, leaves and reproductive structures, these mainly referring to the Glossopterids, and seeds, all usually preserved as impressions/compressions (Dolianiti, 1946, 1948, 1952, 1953a-c, 1954a,b, 1956a,b, 1971; Barbosa, 1958; Millan, 1967a,b, 1969a,b, 1971; Yoshida, 1966, 1968; Rigby, 1969a,b, 1972a,b; Bernardes-de-Oliveira, 1969, 1977, 1978, 1980a,b, 1988; Bernardes-de-Oliveira \& Carvalho, 1981; Bernardesde-Oliveira \& Pontes, 1977; Bernardes-de-Oliveira \& Yoshida,
1982). This locality is representative of the typical post-glacial gondwanic flora, "Glossopteris Flora", associated with coal deposits, and it is of great importance in the understanding of the depositional environments and the coalgenerating processes of the "Irapuá Bed", besides having contributed, together with other like sites in austral continents, to proving the existence of the ancient "Gondwana Continent" (Iannuzzi, 2002). However, the sphenophyte group is rare in this association, being represented by a few specimens of Notocalamites askosus (Rigby, 1972a), Paracalamites australis Rigby, 1966, Phyllotheca australis Brongniart, 1828, Phyllotheca griesbachii Zeiller, 1902 and only one described sample, until this research, with some doubt, as (?) Sphenophyta fructification (Bernardes de Oliveira, 1977, 1988).

Recently, technical visits by the senior author to the major repositing collections of material from the Bainha Outcrop and nearby localities, namely Instituto de Geociências of the Universidade de São Paulo (IG-USP), $9^{\text {th }}$ District of the Depar- 

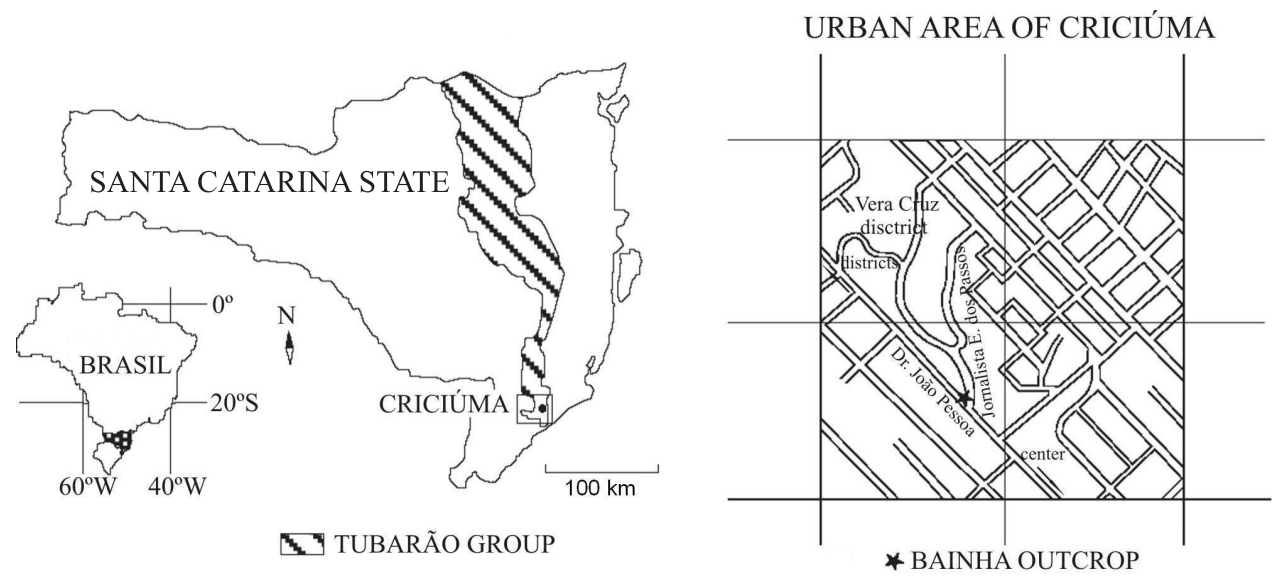

Figure 1. Location map of the Bainha Outcrop, Santa Catarina State (from lannuzzi, 2002).

tamento Nacional de Produção Mineral (DNPM-RJ) and Museu Nacional (MN-UFRJ), besides the examination of the material from the Paleobotanical Collection of the Departamento de Paleontologia e Estratigrafia at the Universidade Federal do Rio Grande do Sul (DPE/UFRGS), allowed us not only to locate the possible Sphenopsida fructification mentioned by Bernardesde-Oliveira $(1977,1988)$ but also to find some unpublished specimens such as this last one from the Bainha Outcrop. This has allowed the confirmation of the presence of two other types of reproductive structures typical of sphenophytes in this megaflora, besides the one already described, Notocalamites askosus (Rigby, 1972a). Therefore, the specimens classified by Guerra-Sommer et al. (1995) as Gondwanostachys australis, from the Quitéria Outcrop, top of the Rio Bonito Formation at Rio Grande do Sul State were also used since they showed a close likeness to one of the detected forms.

\section{MATERIAL AND METHODS}

The material studied is composed of seven specimens, relatively well preserved as adpressions, three of them showing parts and counterparts, where they are reposited at IG-USP (specimen GP/3T 195, mentioned by Bernardes-de-Oliveira, 1977, 1988), DNPM-RJ (five specimens, DGM-Pb 793, 794/803, 798/ 805, 801 and 807ab) and DPE-UFRGS (specimen MP-Pb 403). The material described and published by Guerra-Sommer et al. (1995), reposited at DPE-UFRGS, was totally revised.

The taxonomic study of the material was carried out by examination with the naked eye and a stereoscopic microscope (Magnifier Wild, Model M5-86360), and using high-quality photographs, obtained with and without immersion in alcohol, in order to highlight the details, from which the measurements were made with a vernier caliper and the specimens described. The suprageneric systematic used in this research follows the one of Stewart \& Rothwell (1993). In order to describe and compare the analyzed specimens, an extensive gathering of the characteristics used by different authors in the study of reproductive structures of the Sphenopsida group was carried out. Thus, the following characteristics were selected: general dimensions, organization of the reproductive system (arrangement of the fertile regions along the axes), type of sporangiophore, and kind of leaf whorl associated with the type of axis.

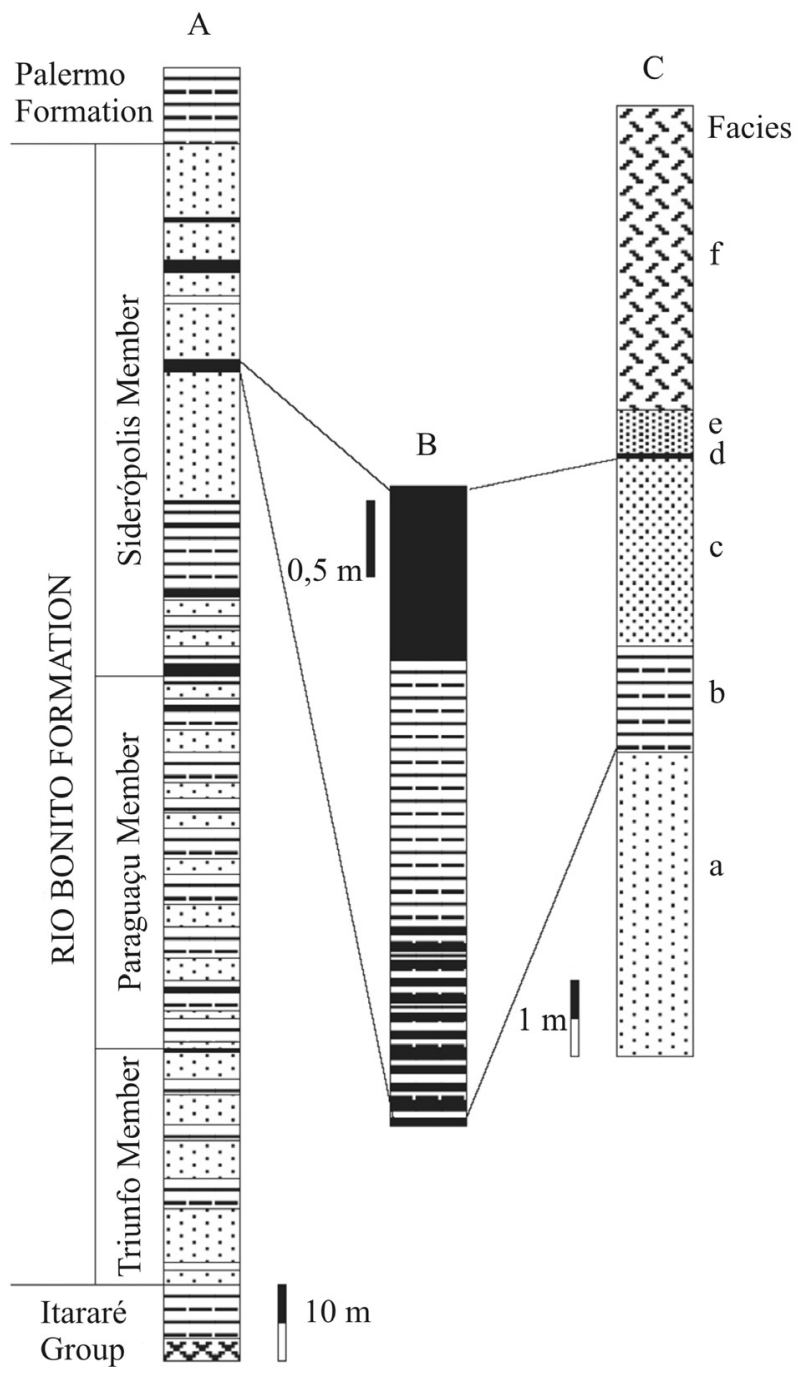

CAPTION OF THE COLUMNS "A" AND "B"

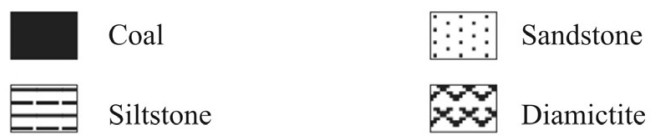

Figure 2. Stratigraphic sections of the: A, Rio Bonito Formation; B, Irapuá Coal Bed; C, Bainha Outcrop, in coal region of Criciúma (based on lannuzzi, 2002a,b). 


\section{SYSTEMATIC PALEONTOLOGY}

The analysis of the material studied allowed us to classify the two morphospecies found as belonging to the genus Giridia, of the Giridih coalfield, Karharbari stage, Lower Permian of India. The reproductive structure previously described as (?) Sphenophyta fruiting (Bernardes-de-Oliveira, 1977, 1988), along with five other unpublished specimens, was classified as the type-species of the genus, Giridia indica Pant, Nautiyal, Misra, 1981. The other form found allowed the proposal of a new species for the genus, since it proved to be like the material from the Quitéria Outcrop, at Encruzilhada do Sul, Rio Grande do Sul State, which shows a better preservation and has been previously described as Gondwanostachys autralis (Guerra-Sommer et al. 1995).

\section{Division TRACHEOPHYTA \\ Class SPHENOPSIDA \\ OrderEQUISETALES}

Family PHYLLOTHECACEAE

Genus Giridia Pant, Nautiyal \& Misra, 1981

Type-species. Giridia indica Pant, Nautiyal \& Misra, 1981.
Giridia indica Pant, Nautiyal \& Misra, 1981

(Figure 3)

1988 (?) Sphenophyta fructification Bernardes-de-Oliveira, p. 54-55, est. II, fig. 5 .

Specimens studied. GP/3T 195, DGM-Pb 793, 794ab/803 (parts and counterparts), 798ab/805 (parts and counterparts), 801, 807ab.

Description. The material studied comprises six fragments of reproductive portions of Sphenophyta, three of them composed of parts and counterparts that show a good preservation as adpressions. The specimens are constituted by striated axis fragments that can be longer than $80 \mathrm{~mm}$ (DGM-Pb 794, Figure 3A), divided into nodes and internodes, with the fertile portions inserted in the nodal regions, right below the leaf whorl (Figures 3A-D). The internodes show a width/length ratio between 1:2.6 and 1:4.3. The leaves start at the node and are fused at the base, forming a short sheath, and at their free part is a lanceolate with an acute apex (DGM$\mathrm{Pb}$ 807ab, GP/3T 195, DGM-Pb 801, Figures 3B-D). There are, from what can be observed, up to nine leaves by leaf whorl, taking into account the fragmented state of the specimens.

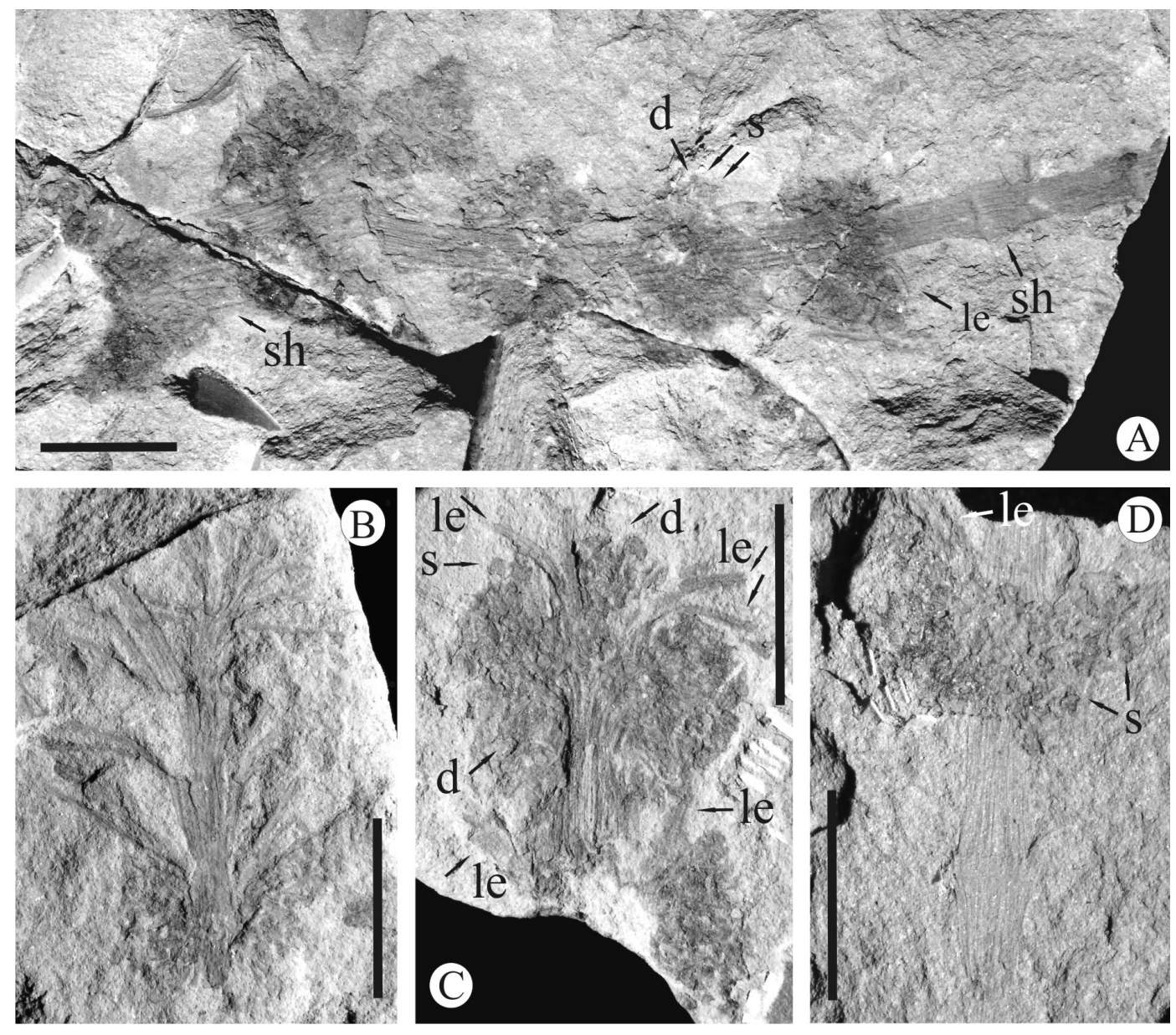

Figure 3. Giridia indica Pant, Nautiyal \& Misra, 1981. A, DGM 794ab, general view of the reproductive system, showing the organization of sporangiophores inserted at the nodes, immediately below the leaf whorls; B, DGM 807ab, distal portion of the fertile axis with a fertile node and other three vegetative nodes, where it is possible to observe a short sheath and the free portion of leaflet; C, GP/3T 195, two fertile nodes with apparent free portion of leaflets; D, DGM 801, fertile axis with clear ribs and apparent free portion of leaflet. Abbreviations: d, bifurcation of the sporangia-bearing sporangiophores; le, free portion of leaflets; s, sporangiophores; sh, sheath. Scale bars = $10 \mathrm{~mm}$. 
The reproductive branches have up to five fertile regions distributed in the medium portion of the axes, extending almost to the apex, sometimes showing internodes with (DGM-Pb 807ab, Figure 3B) or without (DGM-Pb 794ab, Figura 3A) leaf whorls and lacking reproductive structures in the most distal vegetative portions. The fertile regions form dense masses of dichotomized branched sporangiophores which due to their dense arrangement allow only the visualization of the more distal bifurcation (GP/3T 195, Figure 3C). The individual sporangia are round in shape to slightly oval, with diameter varying from 0.9 to $1.5 \mathrm{~mm}$, and are connected to the ends of the bifurcated stalks of the sporangiophores (Figure 3C).

Discussion. The specimens studied show a general organization of the reproductive system with whorls of sporangiophores inserted at the node, immediately below the leaf whorls, in the upper parts of the internodes. This kind of organization differs from that of Phyllotheca australis Brongniart, 1828 emend. Townrow (1955), later on treated informally as Gondwanostachys autralis by Meyen (1967), which shows the sporangiophores connected to the leaf whorl at the basal or lower portion of the internode, which is above the leaf whorl. They differ also from the Notocalamites askosus Rigby (1972a), Pothocites benavidese Dower (1999; illustrated in Iannuzzi et al. 1998) and Peltotheca furcata Escapa \& Cúneo (2005) since they do not show sporangiophores along the whole internode. On the other hand, the organization of the reproductive system of the forms analyzed here is similar to that of other fertile forms of Sphenopsida, such as Giridia indica of Pant et al. (1981), Gondwanites subtilis of Césari \& Loinaze (2006) and the species classified as Cruciaetheca of Cúneo \& Escapa (2006).

The sporangiophores found in the material studied, apparently many times bifurcated, form clusters with individual sporangia connected to the stalks of the last bifurcation. It thereby differs from the three described species for Cruciaetheca Cúneo \& Escapa (2006) that show each one of its sporangiophores composed of only one stalk connected directly to the axis, where four sporangia inserted in the distal portion form a cross, as well as from the Gondwanites subtilis (Césari \& Loinaze, 2006), a species in which the sporangiophore is composed of a simple terminal sporangium also connected by only one stalk directly to the axis. On the other hand, this kind of structure of the sporangiophore, found in the material studied, shows the same characteristics found in Giridia indica.

Thus, the similarities observed both in the organization of the reproductive system and the type of sporangiophore allow us to include the studied specimens in the genus Giridia. Besides, the shape of the leaves at their free part are lanceolate with an acute apex and the formation of a short leaf sheath along the node are other features that approximate our specimens to the Giridia indica. It is worth noting that both the Indian and the Brazilian specimens lack sufficient detail, and thus, it is necessary to study new specimens in order to elucidate the structure of the dense mass of sporangiophores that remain imprecise.

Giridia quiteriensis sp. nov. (Figures 4-5)

1995 Gondwanostachys australis (Meyen). Guerra-Sommer, Cazzulo-Klepzig \& Marques-Toigo, p. 70-72, lâms. 1-2.
Holotype. MP-Pb 2863.

Paratypes. MP-Pb 403, 2864, 2874.

Described specimen. MP-Pb 403.

Revised material. MP-Pb 2863;2864; 2874.

Type-locality and type-horizon. Quitéria Outcrop, Encruzilhada do Sul, Rio Grande do Sul State; Rio Bonito Formation, Paraná Basin.

Other localities and horizon. Bainha Outcrop, Criciúma, Santa Catarina State; "Irapuá" Bed of the Siderópolis Member, Rio Bonito Formation, Paraná Basin.

Etymology. The name refers to the Quiteria Outcrop, at Encruzilhada do Sul, Rio Grande do Sul State, where the better preserved specimens of the species are found, which were published for the first time under another designation.

Diagnosis. Ribbed axes with nodes and internodes that bear Phyllotheca-type leaf whorls forming a prominent and rigid sheath curved downwards with whorls of sporangiophores inserted immediately below the leaf whorls. Each sporangiophore whorl is formed of the stalks several times dichotomized, ending in single sporangia. Sporangia are single, rounded to slightly oval in shape, connected to terminal stalks. If preserved, there are Calamospora-type miospores.

Description. The specimen studied, MP-Pb 403, consists of a fragment of the reproductive portion of sphenophyta, preserved as adpression (Figures 4A-B). The fertile axis is composed of a striated axis with a length of $45 \mathrm{~mm}$ and, on average, $4.3 \mathrm{~mm}$ wide, with two clear node regions showing a width/length ratio of 1:4.4. In this specimen it is possible to visualize only one node region with whorl of sporangiophore inserted directly below the leaf whorl (Figures 4A-B). The leaf whorls start fused at the node regions forming an extensive sheath of a coriaceous aspect, recurved towards the basal portion of the axis, where the basal portion of each leaflet is easily individualized through a line of leaf lamina union or fusion. The free part of the whorls is not very clear, but it is possible to observe that they are directed from the sheath to the basal portion of the stalk. The fertile region, located right below the node, forms only one whorl composed of a dense mass of sporangiophores, whose axes apparently have multiple ramifications, which, due to its dense arrangement, allow us to observe only the most distal bifurcations of this system. The sporangia are individual, round to slightly oval in shape, with diameters from 0.9 to 1.6 $\mathrm{mm}$, and are connected to the ends of the bifurcated stalks of the sporangiophores (Figure 4B).

Remarks. The material described here, MP- $\mathrm{Pb} 403$, comes from the Bainha Outcrop, at Criciúma, Santa Catarina State, but has proven to be extremely similar to the fertile specimens described in 1995 by Guerra-Sommer et al. as Gondwanostachys australis, from the Quitéria Outcrop at Encruzilhada do Sul, Rio Grande do Sul State, as illustrated in plates 1 and 2 of that paper. In examining this specimen already described, it is verified that these show characteristics very similar to those found in the material from Bainha, in the organization of the reproductive system, in the type of sporangiophores, in the type and length of the sheath and in the overall dimensions of the specimens (Figures 5A-D). However, these features were not described by the authors (p. 68 and 72).

Actually, throughout the description of the Gondwanostachys australis, some characteristics mentioned by Guerra-Sommer et al. (1995) are not in line with what is observed in the illustrations (1995, lâm. 1, fig. a-d) or directly 

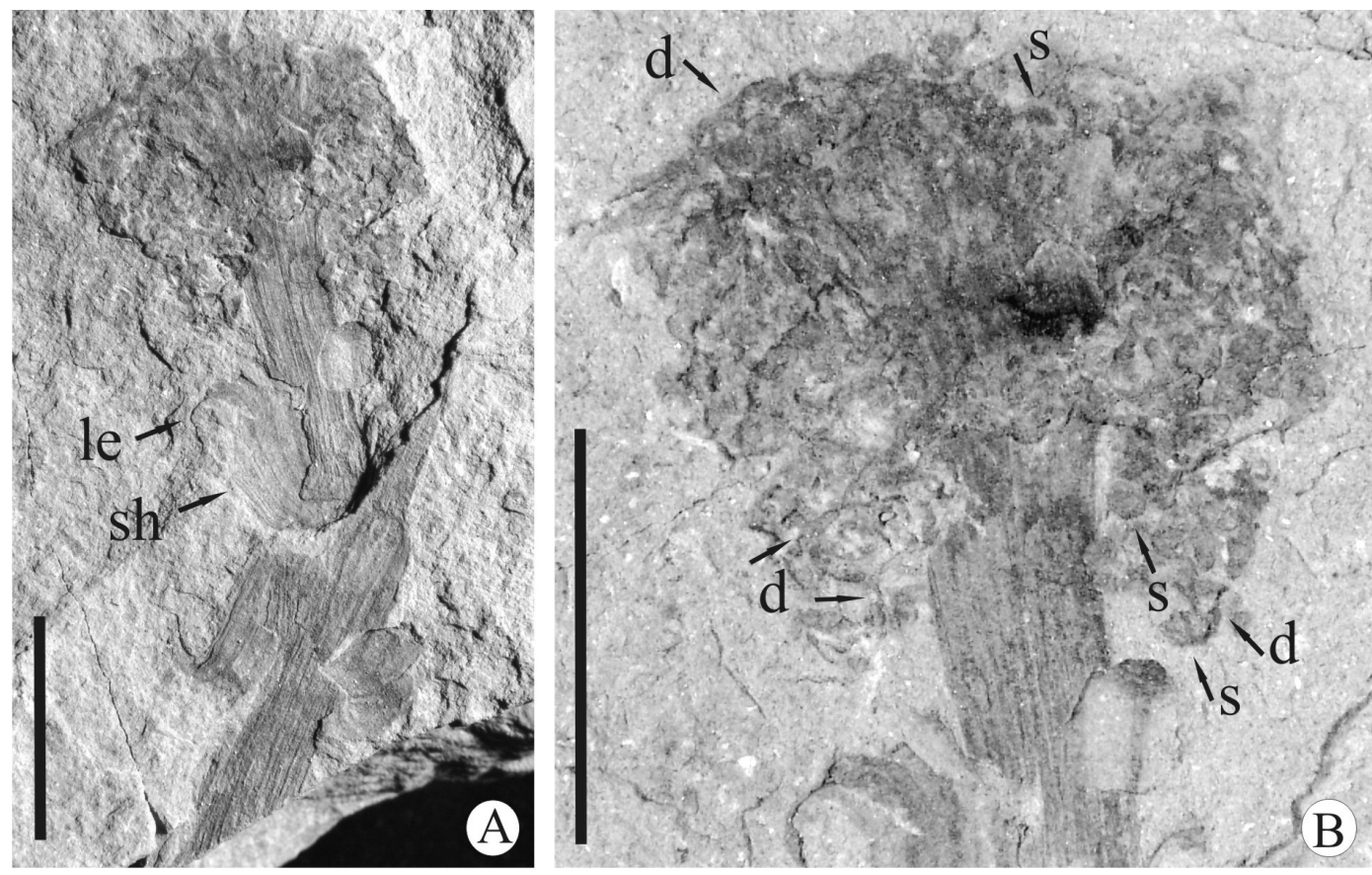

Figure 4. Giridia quiteriensis sp. nov., from the Bainha Outcrop. A, MP-Pb 403, general view of the reproductive system, showing the organization of fertile region densely arranged with sporangiophores inserted at the node, immediately below the leaf whorls, and a node with a leaf whorl in which it is possible to observe a prominent and rigid (coriaceous) sheath; $\mathbf{B}$, detail of A, showing clear bifurcation of the sporangia-bearing sporangiophores. Abbreviations: d, bifurcation of the sporangia-bearing sporangiophores; le, free portion of leaflets; s, sporangiophores; sh, sheath. Scale bars $=10 \mathrm{~mm}$.

in the material itself. It is mentioned in the text the term strobilus or strobilus axis while it is clearly a non-strobilar reproductive structure, made up of an articulated axis with several fertile regions along these axes. The authors describe yet that the sporangiophores start at the lowermost portion of the internode, which means, right above the node from where the leaf whorl emerges. However, this kind of structure is very well illustrated by Meyen (1987, fig. 28b) and Boureau (1964) to designate the species Phyllotheca (= Gondwanostachys) australis of Townrow (1955), not occurring in the material of the Quitéria outcrop, in which the whorl of sporangiophores starts right below the very wellnoted node, from where the leaf whorl emerges as a sheath curving towards the base of the axis, as if forming a protective canopy for the whorl of sporangiophores located right below (Figures 5C-D; Guerra-Sommer et al., 1995, pl. 1, figs. b-c). Finally, these authors describe a fertile region as having unique axes of sporangiophores that subdivide the originating peltate structures bearing elongated and anathropous sporangia (Guerra-Sommer et al., 1995, p. 68 and 72). The direct observation of the specimens revealed that it is impossible to elucidate the structuring of the subdividing system of the sporangiophores in the fertile whorl, since it is formed by a dense mass of almost shapeless sporangiophores. What can be realized is that the sporangiophores apparently display multiple subdivisions, which, due to its dense arrangement, only allows viewing of the more distal bifurcations of this system. These last order bifurcations bear simple terminal sporangia without any peltate structure (Figures 5B-D). This same incompatibility between the original description of the material of the Gondwanostachys australis made by Guerra-Sommer et al. (1995) and what the illustrations of the specimens showed in the paper had already been noticed by Cúneo \& Escapa (2006), who thereby raised the possibility of this material belonging to the genus Giridia or Cruciaetheca or even a new genus.

Thus, the description of the fertile portion of the material coming from the Quitéria Outcrop (Guerra-Sommer et al., 1995) is actually compatible with the above description for the specimen $\mathrm{MP}-\mathrm{Pb}$ 403. The dimensions of the vegetative portions of the axes and branches published by GuerraSommer et al. (1995) are in accordance with what has been directly observed in the specimens described by those authors. However, there is no mention of the dimensions of the sporangia. In observing the specimens, the authors of this paper were able to measure a few final oval-shaped sporangia (6), and obtained diameters of 0.7 to $1.2 \mathrm{~mm}$, which are, on average, a little smaller than those obtained for the specimen MP-Pb 403 (between 0.9 and $1.6 \mathrm{~mm}$ ). Given the degree of compression, distortion and denseness of the fertile portions of the overall specimens, there is no way to obtain more conclusive measures, and thus, the difference is considered of minor importance. Therefore, it is concluded that both materials, the one from Bainha and the one from Quitéria, belong to the same morphotype or taxon-form.

Discussion. The specimens from Bainha and Quitéria, according to the descriptions above and the prior discussion about Giridia indica, undoubtedly correspond to the genus Giridia, since they have their fertile regions are located right below the node, formed by a dense mass of subdivided sporangiophores that support simple terminal sporangia at the more distal bifurcations of this system.

In this sense, the material of Guerra-Sommer et al. (1995) should inevitably be recombined in Giridia. However, it is worth noting that, when describing the specimens as Gondwanostachys australis, Guerra-Sommer et al. (1995) proposed an emendation to the original diagnosis of the genus-species Gondwanostachys australis, attributed by the 

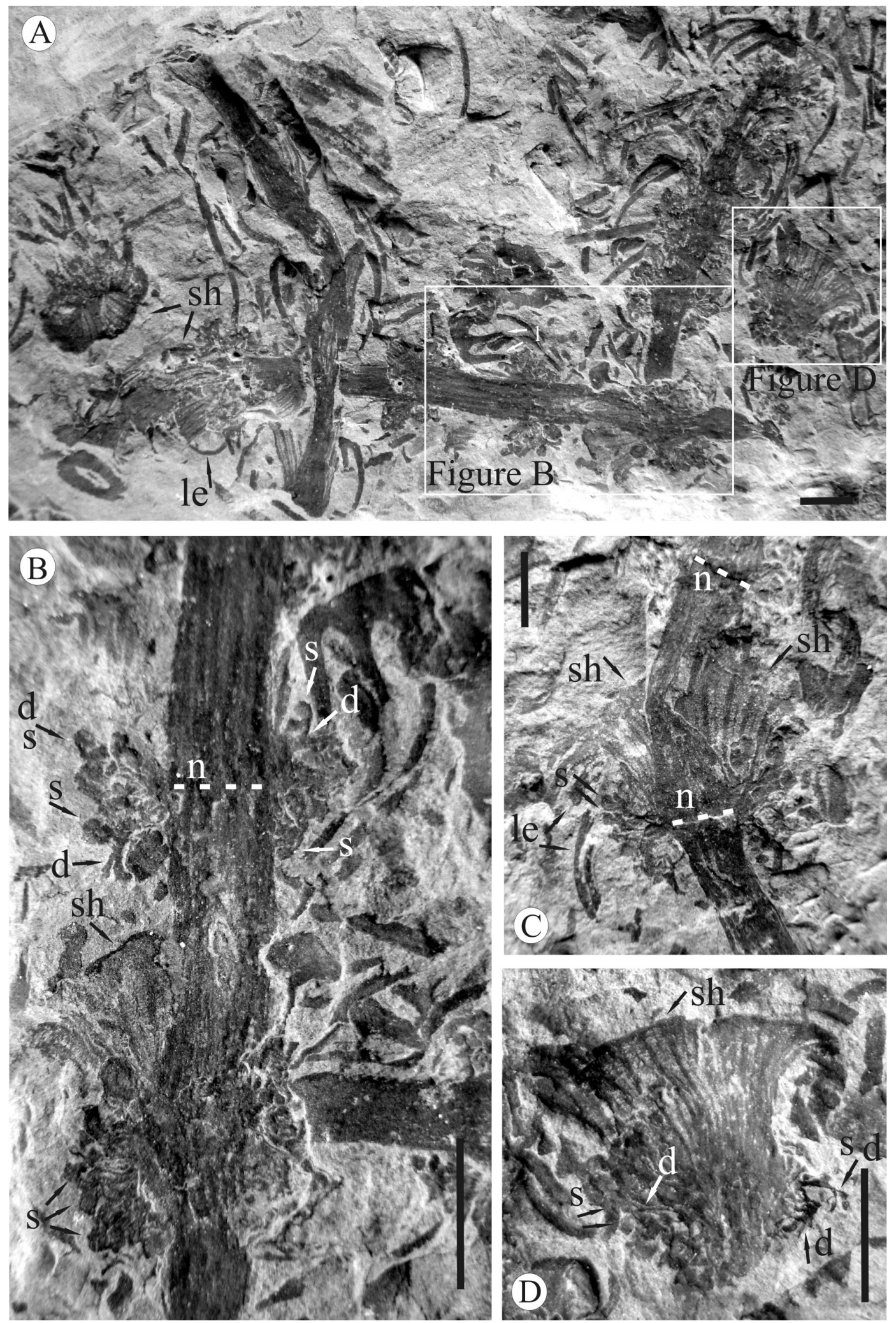

Figure 5. Giridia quiteriensis sp. nov., from the Quitéria Outcrop. A, MP-Pb 2863 (holotype), several specimens in which it is possible to observe the general view of the reproductive system, showing the organization of sporangiophores inserted at the node, immediately below the leaf whorls that are composed of prominent and rigid (coriaceous) sheaths; it is also possible to observe free portions of leaflets, curved towards the basal parts of the axes; B-D, details of specimens shown in A, showing the most distal bifurcations of the sporangia-bearing sporangiophores, the prominent and curved sheaths and free portions of leaflets, diagnostic features of this species. Abbreviations: d, distal bifurcation of the sporangia-bearing sporangiophores; le, free portion of leaflets; $\mathbf{n}$, node; s, sporangiophores; sh, sheath. Scale bars = A and B, $10 \mathrm{~mm}$; C and D, $5 \mathrm{~mm}$. 
authors to S.V. Meyen. The epithet Gondwanostachys has been informally used before by Meyen (1967) to designate the fertile portions of Phyllotheca australis described by Townrow (1955) for forms of the Upper Carboniferous from Australia. Thus, Meyen (1967) never formally erected the genus Gondwanostachys through a description or a diagnosis that would actually correspond to the species Phyllotheca australis as originally established by Townrow (1955). Guerra-Sommer et al. (1995), in turn, have justified their emendation to a supposed diagnosis assigned to Meyen (1967) by the fact that they had extracted Calamospora-type spores from some sporangia in their material. However, there is no way to emend a diagnosis that has not been formalized by its probable author, in this case, S. V. Meyen. Actually, the only possible emendation would be proposed to the diagnosis originally established by Townrow (1955). Therefore, Guerra-Sommer et al. (1995) should not have emended something that had not been formally proposed. In this case, they could be, at best, considered as the formal authors for the genus-species Gondwanostachys australis, if their propositions (description and diagnosis) were also considered to be valid (it has been seen in the previous item, observations), making it hard to emend the diagnosis proposed by Guerra-Sommer et al. (1995). On the other hand, when emending the diagnosis for Gondwanostachys australis, Guerra-Sommer et al. (1995) considered as holotype the specimen described by Townrow (1955) for Australia, which has been determined herein as totally different (see item Discussion in Giridia indica), in terms of its fertile structure, from the Brazilian material attributed to Gondwanostachys australis by the authors.

In conclusion, the taxonomic proposition of GuerraSommer et al. (1995) is not considered valid, since on the one hand, it is based on an inappropriate description of the analyzed material, and on the other hand, it refers to a form (Australian one) very different from the Brazilian material, supposedly co-specific to the type-material of Gondwanostachys australis. Thus, the option stated here is to transfer all the fertile material described by Guerra-Sommer et al. (1995), as Gondwanostachys australis, along with the Bainha specimen, to a new taxon called Giridia quiteriensis sp. nov.. This new species is distinguished from the typespecies of the genus, Giridia indica, basically by having the leaf whorls fused at the base forming better developed sheaths with a coriaceous aspect, which curve towards the fertile portions, apparently, forming a protective canopy. These sheaths are so distinct that they allowed, for example, the clear visualization of the central vein of each leaflet, as well as the lines of lamina union that border each leaflet. This characteristic feature permitted the classification of the forms from Bainha and Quitéria as a new species. The occurrence of Calamospora-type spores, detected by Guerra-Sommer et al. (1995) in the material from Quitéria, was incorporated as one of the possible diagnostic characteristics for Giridia quiteriensis sp. nov.

\section{FINAL CONSIDERATIONS}

The unpublished material referring to the reproductive structures of the Sphenopsida from the Bainha Outcrop, at Criciúma, Santa Catarina State, allowed us to complement the description initiated in the 1980s by Bernardes-de-Oliveira (1988), classifying the material, initially designated (?)Sphenophyta fructification, as Giridia indica Pant et al. (1981). On the other hand, the analysis of an unpublished specimen from the Bainha Outcrop has led to a reevaluation of the material described by Guerra-Sommer et al. (1995) as Gondwanostachys australis from the Quitéria Outcrop, at Encruzilhada do Sul, Rio Grande do Sul State. All this material was considered a new species related to the genus Giridia, named Giridia quiteriensis sp. nov. Thus, for the first time forms related to the Indian genus Giridia are recorded in the Paraná Basin. This is also the first record of this genus outside the Indian Subcontinent, which clarifies even more the relationships between Early Permian Gondwanic floras from South America and India.

\section{ACKNOWLEDGMENTS}

The authors thank Luiz F. Lopez (IGeo-UFRGS) for the preparation of the photographic material, and the Instituto de Geociências of the Universidade de São Paulo (IG-USP) and the $9^{\text {th }}$ District of the Departamento Nacional de Produção Mineral (Brazilian Geological Survey - DNPM-RJ) for lending the material from the Bainha Outcrop for the development of this research. The authors are also grateful to Graciela P. Tybusch who took part in the overall search for this material in the institutional collections. This research was financially supported by the Conselho Nacional de Desenvolvimento Científico e Tecnológico (CNPq) in the form of a scholarship (Process 140631-2006/2) awarded to the senior author, and grants awarded to the coauthor for research support (Processes PQ309322/2007-3 and 483463/2007-8). This paper was a contribution to the XII SBPP (Florianópolis, November 02-05th, 2008).

\section{REFERENCES}

Barbosa, O. 1958. On the age of the Lower Gondwana Floras in Brazil and Abroad. In: CONGRESO GEOLÓGICO INTERNACIONAL, 20, 1958. Proceedings, Cidade do México, p. 205-236.

Bernardes-de-Oliveira, M.E.C. 1969. Flora da Formação Rio Bonito: Glossopteris, Noeggerathiopsis, Sphenopteris, Gangamopteris e Rhabdotaenia, na Subida do Bainha, Criciúma, SC. Faculdade de Filosofia, Ciências e Letras, Universidade de São Paulo, Dissertação de Mestrado, 51 p.

Bernardes-de-Oliveira, M.E.C. 1977. Tafoflora eogondvânica da camada Irapuá, Formação Rio Bonito (Grupo Tubarão), SC. Instituto de Geociências, Universidade de São Paulo, Tese de Doutoramento, 301 p., 2 v.

Bernardes-de-Oliveira, M.E.C. 1978. Frutificações de pteridospermófitas eogondvânicas da Camada Irapuá, Formação Rio Bonito, nos arredores de Criciúma, SC. In: CONGRESSO BRASILEIRO DE GEOLOGIA, 30, 1978. Anais, Recife, SBG, v. 2, p. $986-1001$.

Bernardes-de-Oliveira, M.E.C. 1980a. Tafoflora eogondvânica da Formação Rio Bonito ("Camada Irapuá”), Bacia do Paraná, Brasil. In: CONGRESO ARGENTINO DE PALEONTOLOGÍA Y BIOSTRATIGRAFÍA, 2/CONGRESO LATINOAMERICANO DEPALEONTOLOGÍA, 1, 1978. Actas, Buenos Aires, v. 4, p. 69-88.

Bernardes-de-Oliveira, M.E.C. 1980b. Nouveau genre néomarioptéridien fertile de la Flore à Glossopteris du Bassin de Paraná au Brésil. Boletim do Instituto de Geociências da USP, 11:113-119. 
Bernardes-de-Oliveira, M.E.C. 1988. Equisetales eogondvânicas da "Tafoflora Iarapuá", Formação Rio Bonito (Permiano Inferior), em Criciúma, SC, Bacia do Paraná, Brasil. Anais da Academia Brasileira de Ciências, 60(1):45-60.

Bernardes-de-Oliveira, M.E.C. \& Carvalho, R. G. 1981. Frutificações femininas de glossopteridófitas da Formação Rio Bonito, Grupo Tubarão, Estado de Santa Catarina, Brasil. In: CONGRESSO LATINOAMERICANO DE PALEONTOLOGIA, 2, 1981. Anais, Porto Alegre, UFRGS, p. 181-199.

Bernardes-de-Oliveira, M.E.C. \& Pontes, C.E.S. 1977. Algumas observações sobre cordaitófitas da Formação Rio Bonito, Grupo Tubarão, Bacia do Paraná, Brasil. In: CONGRESO GEOLÓGICO CHILENO, 1, 1976. Actas, Santiago, v. 3, p. 21-81.

Bernardes-de-Oliveira, M.E.C. \& Yoshida, R. 1982. Coniferófitas da "Tafoflora Irapuá", Formação Rio Bonito, Grupo Tubarão, em Santa Catarina. Asociación Latinoamericana de Paleobotánica y Palinología, p. 39-55 (Boletín 8).

Boureau, E. 1964. Traité de Paléobotanique: Sphenophyta. $1^{\mathrm{a}}$ ed, Paris, Masson et cie, v. III, 554 p.

Césari, S.N \& Loinaze, V.S.P. 2006. A new Carboniferous equisetale from western Gondwana. Geobios, 39(6):785-790.

Cúneo, R. \& Escapa, I. 2006. The Equisetalen genus Cruciaetheca nov. from the Lower Permian of Patagonia, Argentina. International Journal of Plant Sciences, 167:167-177.

Dolianiti, E. 1946. Notícias sobre novas formas na Flora do Glossopteris do Brasil Meridional. Rio de Janeiro, Departamento Nacional da Produção Mineral, Divisão de Geologia e Mineralogia, 6 p. (Notas Preliminares e Estudos 34).

Dolianiti, E. 1948. A Paleobotânica no Brasil. Rio de Janeiro, Departamento Nacional da Produção Mineral, Divisão de Geologia e Mineralogia, 87 p. (Boletim 123).

Dolianiti, E. 1952. La Flore Fossile du Gondwana au Brésil D’Apres Sa Position Stratigraphique. In: INTERNATIONAL GEOLOGICAL CONGRESS, SYMPOSIUM SUR LES SERIE DE GONDWANA, 19, 1952. Proceedings, Algers, p. 285-301.

Dolianiti, E. 1953a. A Flora do Gondwana Inferior em Santa Catarina. I. O Gênero Glossopteris. Rio de Janeiro, Departamento Nacional da Produção Mineral, Divisão de Geologia e Mineralogia, 7 p. (Notas Preliminares e Estudos 60).

Dolianiti, E. 1953b. A Flora do Gondwana Inferior em Santa Catarina. II. O Gênero Taeniopteris. Rio de Janeiro, Departamento Nacional da Produção Mineral, Divisão de Geologia e Mineralogia, 7 p. (Notas Preliminares e Estudos 61).

Dolianiti, E. 1953c. A Flora do Gondwana Inferior em Santa Catarina. III. O Gênero Actinopteris. Rio de Janeiro, Departamento Nacional da Produção Mineral, Divisão de Geologia e Mineralogia, 3 p. (Notas Preliminares e Estudos 62).

Dolianiti, E. 1954a. A Flora do Gondwana Inferior em Santa Catarina. IV. O Gênero Vertebraria. Rio de Janeiro, Departamento Nacional da Produção Mineral, Divisão de Geologia e Mineralogia, 5 p. (Notas Preliminares e Estudos 81).

Dolianiti, E. 1954b. A Flora do Gondwana Inferior em Santa Catarina. V. O Gênero Gangamopteris. Rio de Janeiro, Departamento Nacional da Produção Mineral, Divisão de Geologia e Mineralogia, 12 p. (Notas Preliminares e Estudos 89).

Dolianiti, E. 1956a. Um verticilo de Glossopteris no Gondwana do Estado de Santa Catarina. Anais da Academia Brasileira de Ciências, 28(1):115-118.

Dolianiti, E. 1956b. A Flora do Gondwana Inferior em Santa Catarina. VI. O Gênero Sphenopteris: Brasil. Rio de Janeiro, Departamento Nacional da Produção Mineral, Divisão de Geologia e Mineralogia, 18 p. (Notas Preliminares e Estudos 95).

Dolianiti, E. 1971. A Flora do Gondwana Inferior em Santa Catarina. VII. O Gênero Ottokaria, Ottokaria sanctacatarinae n. sp.. Anais da Academia Brasileira de Ciências, 43(Suplem.):337-342.
Dower, B.L. 1999. Sphenipsids from the Early Carboniferous of Paracas (Peru): implications for sphenopsid evolution in Gondwana. University of Pennsylvania, Ph.D. thesis, 130 p.

Escapa, I. \& Cúneo, R. 2005. A new equisetalean plant from the early Permian of Patagonia, Argentina. Review of Palaeobotany and Palynology, 137:1-14.

Guerra-Sommer, M.; Cazzulo-Kleipzig, M. \& Marques-Toigo, M. 1995. Gondwanostachyaceae (Equisetopsida) no Gondwana SulBrasileiro (Formação Rio Bonito) com Mega e Microflora associados. Pesquisas, 22:64-73.

Iannuzzi, R.; Pfefferkorn, H.W.; Díaz-Martínez, E.; Alleman, V. \& Suarez-Soruco, R. 1998. La flora eocarbonifera de la Formacion Siripaca (Grupo Ambo, Bolivia) y su correlación con la flora de Paracas (Grupo Ambo, Peru). Boletín de la Sociedad Geológica del Peru, 88:39-51.

Iannuzzi, R. 2002. Afloramento Bainha (Criciúma), SC - Flora Glossopteris do Permiano Inferior. In: C. Schobbenhaus; D.A. Campos; E.T. Queiroz; M. Winge \& M.L.C. Berbet-Born. (eds.) Sítios Geológicos e Paleontológicos do Brasil, DNPM, CPRM, SIGEP, p. 23-31.

Meyen, S.V. 1967. New data on the relationship between Angara and Gondwana Late Paleozoic floras. In: IUGS SYMPOSIUM, 1, 1967. Proceedings, Buenos Aires, p. 144-152.

Meyen, S.V. 1987. Fundamentals of Paleobotany. $1^{\text {st }}$ ed., New York, Chapman and Hall, 432 p.

Millan, J.H. 1967a. O Gênero Samaropsis na Flora do Gondwana do Brasil e outros países. Rio de Janeiro, Museu Nacional, 12 p. (Geologia, Boletim 3).

Millan, J.H. 1967b. Novas frutificações na Flora de Glossopteris do Gondwana Inferior do Brasil. Dolianitia gen. nov. Rio de Janeiro, Departamento Nacional da Produção Mineral, Divisão de Geologia e Mineralogia, 19 p. (Notas Preliminares e Estudos 140).

Millan, J.H. 1969a. The Gymnospermic and Platyspermic seeds of the Glossopteris Flora from Brazil and correlated foreign regions. In: IUGS SYMPOSIUM, 1, 1967. Proceedings, Buenos Aires, p. 107-122.

Millan, J.H. 1969b. Sobre Plumsteadiella um novo vegetal comum ao Gondwana Inferior do Brasil e da África do Sul. Plumsteadiella apeidicellata sp. nov. Rio de Janeiro, Museu Nacional, 8 p. (Geologia, Boletim s/n.).

Millan, J.H. 1971. Ocorrência de folhas de Noeggerathiopsis presas a um eixo caulinar, no Gondwana do estado de Santa Catarina. Anais da Academia Brasileira de Ciências, 43(Suplem.):343-350.

Pant, D.D.; Nautiyal, D.D. \& Misra, L. 1981. Giridia indica gen. et sp. nov. the possible cone of Phyllotheca indica Bunbury. Paleontographica Abt. B, 176:174-178.

Rigby, J.F. 1969a. The Lower Gondwana Scene. Boletim Paranaense de Geociências, 27:1-13.

Rigby, J.F. 1969b. Rhodea criciumana sp. nov., a new plant from the Tubarão Group of Brazil. Boletim Paranaense de Geociências, 27:111-122.

Rigby, J.F. 1972a. The Notocalamitaceae, a new family of Upper Palaeozoic Equisetaleans. The Palaeobotanist, 19(2):161-163.

Rigby, J.F. 1972b. On Arberia White and some related Lower Gondwana female fructifications. Palaeontology, 15(1):108-120.

Stewart, W.N. \& Rothwell, G.W. 1993. Paleobotany and the evolution of plants. $1^{\text {st }}$ ed. Cambridge, Cambridge University Press, $521 \mathrm{p}$.

Townrow, J.A. 1955. On some species of Phyllotheca. Journal Proceedings of the Royal Society of NSW, 89:39-63.

Yoshida, R. 1966. Nota sobre um tufo de Glossopteridae na Camada Irapuá, Criciúma, SC. São Paulo, SBG, p.69-77 (Boletim 15)

Yoshida, R. 1968. Descrição preliminar de Coníferas Neopaleozóicas da Bacia do Paraná. Faculdade de Filosofia, Ciências e Letras, Universidade de São Paulo, Dissertação de Mestrado, 54 p.

Received in January, 2009; accepted in January, 2010. 